\title{
HOSPITALINĖ GRAMNEIGIAMŲ LAZDELIŨ BAKTERIEMIJA INTENSYVIOSIOS TERAPIJOS SKYRIUJE: KĄ TURIME ŽINOTI?
}

\author{
Dalia Adukauskienè $\dot{1}^{1}$ Mantas Jurevičius ${ }^{1}$, Viktorija Micpovilytė ${ }^{1}$, Dovilè Valančienėe ${ }^{2}$, \\ Asta Dambrauskiené $\dot{3}^{3}$ \\ ${ }^{l}$ Lietuvos sveikatos moksly universiteto Medicinos akademijos Intensyviosios terapijos klinika, \\ ${ }^{2}$ Klaipedos jürininku ligoninès Anesteziologijos ir intensyviosios terapijos skyrius, \\ ${ }^{3}$ Lietuvos sveikatos mokslu universiteto Medicinos akademijos Laboratorinès medicinos klinika
}

Raktažodžiai: bakteriemija, gramneigiamos lazdelès, intensyviosios terapijos skyrius.

\section{Santrauka}

Hospitalinė gramneigiamų lazdelių bakteriemija dažniausiai nustatoma intensyviosios terapijos skyriuje ir sietina su didejančiu sergamumu ir dideliu mirštamumu, siekiančiu iki 60 procentų. Dažniausioms šių sukèlejų padermèms būdingas dauginis atsparumas antibiotikams, todèl antibiotiko pradinis paskyrimas dažnai esti netinkamas. Ligos baigti gerina ankstyvoji tinkama empirinè antibiotikų terapija. Svarbu anksti atpažinti šią sunkią paciento būklę, prognozuoti galimus sukèlèjus, įvertinti jų dauginio atsparumo antibiotikams padermių rizikos veiksnius ir suformuoti neatidèliotino adekvataus empirinio antibakterinio gydymo pagrindą. Tyrimo tikslas - apžvelgti gramneigiamų lazdelių bakteriemijos klasifikaciją, epidemiologinę situaciją intensyviosios terapijos skyriuose, diagnostikos ir gydymo principus, bakterijų daugini atsparumą antibiotikams ir mirštamumo rizikos veiksnius. Atlikta mokslinès literatūros šaltinių apžvalga ir analizè. Publikacijų paieška atlikta tarptautinėse medicinos duomenų bazėse PubMed, ScienceDirect. Straipsnyje apžvelgiama mokslinẻ literatūra hospitalinès gramneigiamų lazdelių bakteriemijos tema, aptariama jos klasifikacija, epidemiologine situacija intensyviosios terapijos skyriuose, diagnostikos ir gydymo principai, dauginio atsparumo antibiotikams padermés hospitalinès infekcijos ir mirštamumo rizikos veiksniai. Prieita prie išvados, kad hospitalinè gramneigiamų lazdelių bakteremija intensyviosios terapijos skyriuose dažnèja. Sukèlèjai - Klebsiella pneumoniae, Pseudomonas aeruginosa, Acinetobacter baumannii ir Escherichia coli. Jų padermèms būdingas dauginis atsparumas antibiotikams, kurio rizikos veiksniai - su sveikatos priežiūra sietina infekcija, senyvas amžius, buvęs plataus veikimo spektro antibiotikų vartojimas, kritinè paciento būklè (poreikis gydymui ITS), agranulocitozè, medicininiai svetimkūniai, dirbtinè plaučių ventiliacija. Greitas sunkios būklès atpažinimas, infekcijos židinio nustatymas, adekvačios antibiotikų terapijos skyrimas ir optimizuota jos trukmè gerina ligos baigtị bei mažina atsparumą antibiotikams. Mirštamumo rizikos veiksniai - gramneigamų lazdelių bakteriemijos sukèlejo padermès dauginis atsparumas antibiotikams, imunosupresinè būklè, lètinès širdies, kraujagyslių bei plaučių ligos, dirbtinè plaučių ventiliacija, neadekvati empirinè antibiotikų terapija.

\section{Ivadas}

Gyvybingų bakterijų buvimas kraujyje vadinamas bakteriemija, kuri patvirtinama mikroorganizmo išauginimu iš kraujo pasèlio [1]. Teigiamas pasèlio rezultatas, susietas su paciento laboratoriniais ar (ir) klinikiniais sisteminio uždegimo požymiais, gali būti kliniškai reikšminga ir grèsminga bakteriemija [2]. Gramneigiamų lazdelių (toliau - GNL) sienelëje esantis endotoksinas (lipopolisacharidas) skatina uždegimines organizmo kaskadas ir gali sukelti sepsinį šoką [6]. Dažna gramneigiamų lazdelių bakteriemija (toliau GNLB) intensyviosios terapijos skyriuose (toliau - ITS) didina kritinių būklių pacientų sepsinio šoko riziką, ilgina stacionarizavimo trukmę, didina gydymo kaštus ir sukelia iki 60 proc. siekiantị mirštamumą $[7,8]$. Medicinos technologijų ir farmacijos pažanga, kvejpavimo ir kraujotakos palaikymo invazinių galimybių tobulinimas ir jų taikymas gerina pacientų išgyvenamumą, tad ị ITS patenka vis daugiau senyvo amžiaus, sergančių daugeliu lètinių ligų, imunosupresinès būklès, po organų transplantacijos pacientų, kuriems 
kyla didžiausia rizika susirgti minèta infekcija [4,5]. Kita mirštamumo dèl bakteriemiju grèsmè - didejjantis mikroorganizmų atsparumas antibiotikams [5]. Siekiant kontroliuoti GNLB ir išvengti nepalankios baigties, nepakanka gerai išmanyti epidemiologinę situaciją. Reikia gerai suvokti ir atpažinti šios infekcijos rizikos veiksnius, tinkamai parinkti ir efektyviai taikyti prevencijos priemones, greitai diagnozuoti ir optimaliai gydyti.

Tyrimo tikslas - apžvelgti GNLB klasifikaciją, epidemiologinę situaciją ITS, diagnostikos ir gydymo principus, bakterijų dauginį atsparumą antibiotikams ir mirštamumo rizikos veiksnius.

\section{Tyrimo objektas ir metodai}

Atlikta literatūros šaltinių apžvalga ir analizè. Publikacijų paieška anglų kalba atlikta tarptautinèse medicinos duomenų bazėse PubMed, ScienceDirect. I apžvalgą įtrauktos tik anglų kalba paskelbtos publikacijos, atitinkančios tyrimo temą.

\section{Tyrimo rezultatai ir jų aptarimas}

Klasifikacija. Pagal šaltinị bakteriemija skirstoma ị pirminę ir antrinę: pirminè, kai infekcijos židinys nenustatomas; antrine - kai nustatomas lokalus infekcijos židinys, iš kurio tos pačios bakterijos patenka ị kraują. Infekcijos šaltinis gali būti ir centrinès ar periferinès venos kateteris, kurị kai kurie autoriai ịvardija kaip atskirą antrinès bakteriemijos tipą - kateterio infekciją [3-5].

Pagal igijimo vietą infekcijos klasifikuojamos ị visuomenejje igytą, hospitalinę ir susijusią su sveikatos priežiūros įstaigomis [3]. Šis skirstymas leidžia nuspèti galimus sukėlejus, jų atsparumą antibiotikams ir iš karto numatyti tinkamiausią gydymą. Hospitalinè infekcija nustatoma praejjus $\geq 48$ val. po stacionarizavimo. Kai kurie autoriai, analizuodami ITS bakteriemijas, susiaurina klasifikaciją ir išskiria ITS ịgytą infekciją, kuri apibrèžiama kaip po 72 val. nuo atvykimo i ITS nustatyta infekcija, arba nustatyta per $\geq 48$ val., susijusi su atliktomis intervencijomis (pvz.: intraveninio kateterio ịterpimu, šlapimo pūslès kateterizavimu, bronchoskopija ir kt.) [3].

Epidemiologija. Bakteriemijos pasireiškimo dažnis ir sukèlèjai ịvairiose šalyse, ligoninèse bei gydymo ịstaigu skyriuose yra skirtingi. Ankstesniais literatūros duomenimis, bakteriemijos dažnis ITS yra apie 5 proc. visų pacientų, iš kurių GNLB sukèlejjai nustatyti iki 25-34 proc. atvejų $[9,10]$. Pastaraisiais metais pastebima GNLB didejjimo tendencija: 2012 m. „Eurobact“" studija, kurioje ištirti 1156 bakteriemijos atvejai iš 24 Europos šalių ITS, nustatè, kad GNB sudare jau 58,3 proc. visų bakteriemijų [11]. Šiuo metu vykdomas tęstinis „Eurobact II“ tyrimas, kuriuo remiantis bus įmanoma geriau suvokti dabartinę epidemiologinę situaciją Europos ITS.
GNLB rizikos veiksniai kritinių būklių pacientams yra kritinè klinikinè būklè, invazinių priemonių naudojimo gausa (dirbtinè plaučių ventiliacija, intraveniniai, šlapimo kateteriai), pakaitinès inkstų terapijos poreikis, chirurginè intervencija, būklè po solidinio organo transplantacijos, ịvairialypè imunosupresinè būklè, ilgalaikis ịvairių antibiotikų vartojimas, ilga gydymo ligoninėje trukmè ir kita $[4,5,7]$.

Vienas svarbiausių GNLB kontrolès uždavinių yra nustatyti infekcijos židinị, kad galima būtų nuspèti labiausiai tikètiną infekcijos sukèlèją, kuo anksčiau paskirti tinkamą empirinį antibakterini gydymą ir adekvačiai sanuoti infekcijos židinį. Dažniausiai pirminiai GNLB židiniai ITS yra kvėpavimo takuose (toliau - KvT) (ypač su dirbtine plaučių ventiliacija susieta KvT infekcija), pilvo ertmèje, šlapimo takuose bei centrinès venos kateteriuose [8, 10-12]. Neretai židinys lieka nenustatytas. Pirminès bakteriemijos dažnis siekia iki 30 procentų [7].

Sukẻlẻjai ir jų atsparumas antibiotikams. Literatūros duomenimis, dažniausi ITS GNLB sukèlèjai yra Klebsiella pneumoniae (toliau - K. pneumoniae), Pseudomonas aeruginosa (toliau - P. aeruginosa), Acinetobacter baumannii (toliau - A. baumannii) ir Escherichia coli (toliau-E. coli) $[4,5,8,13]$.

E. coli, būdama normalios žarnyno mikrobiotos dalis ir pagrindinis aerobas, gali būti ir sunkių intraabdominalinių infekcijų sukèlèja, ypač kritinès būklès pacientams, arba pirminès bakteriemijos priežastis dèl translokacijos iš storosios žarnos ị kraują, pvz.: agranulocitozès, lètinio piktnaudžiavimo alkoholiu ir kitais atvejais $[14,15]$.

K. pneumoniae dažnai kolonizuoja hospitalizuotų pacientų virškinimo traktą, odą ar KvT ir pasižymi labai greitu sklidimu į aplinką per pacientų bei medicinos personalo rankas [16]. K. pneumoniae bakteriemija sietina su KvT, intraabdominaline ir šlapimo organų infekcija [17].

P. aeruginosa yra nefermentuojanti gramneigiama lazdelè, dažnai gamtoje randama vandeningoje aplinkoje. Tai oportunistinis patogenas, dažnai aptinkamas blogesnès imuninès būklès pacientams. P. aeruginosa bakteriemija dažniau sietina su KvT (dirbtinès plaučių ventiliacijos) ir šlapimo organų infekcijomis [18]. P. aeruginosa pasižymi igimtu atsparumu kai kuriems antibiotikams, kadangi išorinè membrana gali būti iš prigimties nelaidi kai kurių antibiotikų molekulèms ar turèti fermentų, šalinančių antibiotiko molekules iš bakterijos ląstelès [19].

A. baumannii - taip pat oportunistinis patogenas, kurio bakteriemija sietina su dirbtinès plaučių ventiliacijos sukeliama KvT infekcija, intraveniniais kateteriais, žaizdų infekcija ir šlapimo organų infekcija [20]. A. baumannii taip pat pasižymi igimtu ir igytu atsparumu kai kuriems antibioti- 
kams, labai gerai išlieka net ant sausų paviršių, todèl sklinda ir išsilaiko ligoninès aplinkoje.

Patogenas, nejautrus bent vienam vaistui iš trijų ar daugiau antibiotikų grupių, ịvardijamas kaip dauginio atsparumo antibiotikams (toliau - DAA) [21]. ,Eurobact" tyrimo duomenimis, GNLB sudaro daugiau nei pusę visų DAA sukèlëjų [11]. Enterobacteriacae šeimos GNLB pasižymi didelio spektro betalaktamazių gamyba, todèl jos gali būti atsparios daugumai betalaktaminių antibiotikų [22]. Tokiais atvejais karbapenemai tampa empirinio antibakterinio gydymo pirmojo pasirinkimo antibiotikais, gerinančiais ligos baigtị, tačiau skatinančiais šiai antibiotikų klasei atsparių infekcijų plitimą, ribojantị sunkių infekcijų gydymo galimybes. „Eurobact" tyrime atsparumas karbapenemui buvo rastas: Acinetobacter spp. 69 proc., Klebsiella spp. 37 proc., Pseudomonas spp. 5,7 proc., tačiau jis ịvairiose šalyse skirtingas, ypač paplitęs Pietų Europoje. Italijoje ir Graikijoje K. pneumoniae atsparumas rezerviniam antibiotikui kolistinui jau siekia iki 20 procentų [11].

Diagnostika. GNLB patvirtinama, kai nustatomas GNL augimas kraujo pasėlyje. Greitas sukèlèjo ir jo atsparumo antibiotikams nustatymas yra adekvataus gydymo, susieto su palankia ligos baigtimi, pagrindas [23]. Mikroorganizmu kultūros išauginimas ir identifikavimas klasikiniais metodais paprastai užtrunka $>48$ val., todèl ieškoma greitesnių būdų mikroorganizmui nustatyti. Klinikineje praktikoje mikrooganizmui ir jo atsparumui antibakteriniams vaistams nustatyti vis plačiau taikoma MALDI-TOF (angl. Matrix-associated laser desorption/ionisation time-of-flight mass spectrometry) technologija. Jos metu išaugintas sukèlèjęs specifiškai apdorojamas ir atliekama jo baltymų analizè, pagal kurią greitai ir tiksliai nustatomas patogenas bei jo atsparumas antibiotikams [24]. Taikant šią technologiją, sukèlèjas identifikuojamas greičiau, nei klasikiniais metodais [25]. Tai ypač aktualu pacientams DAA GNLB atvejais, dẻl infekcijos sąsajos su dideliu mirštamumu [50].

Prokalcitoninas - peptidas, kurị gamina dauguma žmogaus organizmo ląstelių kaip atsaką ị pažaidą (infekciją ar traumą). S. Guo ir kt. (2015), lyginę prokalcitonino vertes gramneigiamos ir gramteigiamos bakteriemijos atvejais, nustate, kad prokalcitonino kiekis gramneigiamos bakteriemijos atveju (26.7 ng/ml, 0.09-188.3) buvo ženkliai didesnis (0.84 $\mathrm{ng} / \mathrm{ml}, 0.05-18.79)$, nei gramteigiamos [26].

Gydymo principai. GNLB gydymas susideda iš skubaus ir tinkamo gydymo antibiotikais, infekcijos židinio kontrolès, tinkamo (dažnai invazinio) gyvybinių funkcijų palaikymo bei atidžios paciento stebėsenos. Židinio kontrolei prireikia chirurginio gydymo, intraveninių kateterių ar svetimkūnių šalinimo.

Antibakterinis gydymas esti empirinis ir tikslinis. Empi- rinis parenkamas racionaliu vertinimu, kai sukèlejjas ir (ar) jo atsparumas antibakteriniams vaistams dar nenustatytas, o tikslinis pradedamas, kai duomenys turimi ne tik apie infekcijos lokalizaciją, bet ir jos sukèlejją bei jo jautrumą antibakteriniams vaistams. Dauguma studijų parode, kad netinkamas empirinès ankstyvosios antibiotikų terapijos paskyrimas GNLB atvejais sietinas su didesniu mirštamumu, o labiausiai reikšmingas veiksnys yra laikas iki tinkamos antibiotikų terapijos paskyrimo [27-29]. Dèl šių priežasčių rekomenduojama gydymo strategija yra empirinis plataus veikimo antibiotikų paskyrimas prieš labiausiai tikètinus sukèlejjus, ir kuo greičiau - antibakterinio veikimo susiaurinimas, pagerèjus paciento būklei ir (ar) sužinojus konkretaus patogeno - infekcijos sukèlejjo jautrumą antibakteriniams vaistams.

Renkantis empirinị antibakterinị gydymą, būtina įvertinti paciento klinikinę būklę, gretutines ligas, kontaktą su sveikatos priežiūros įstaigomis, pasèlių mikroskopijos duomenis (pvz., uždegimui nebūdingas sekretas), vietinę epidemiologinę situaciją (sukèlejjų atsparumas antibiotikams), DAA rizikos veiksnius: kolonizacija DAA patogenais, plataus veikimo antibiotikų vartojimas per pastarąsias 30 dienų, gydymo ITS poreikis, dirbtinè plaučių ventiliacija, šlapimo, kraujagyslių kateterių vartojimas, operacija ar invazinè procedūra per 30 dienų, kritinè paciento būklè, agranulocitozè, su sveikatos priežiūra sietina infekcija, amžius $>65$ metai [30-35]. DAA sukèlejjus veikiančiu antibiotikų pasirinkimas yra ribotas, todèl taikytina kombinuota antibiotikų terapija, teikianti galimybę paveikti daugiau galimų patogenų. Kombinuotos antibiotikų terapijos paskyrimas siejamas su geresne ligos baigtimi, gydant sepsį ar sepsinį šoką, jei infekciją sukẻlè P. aeruginosa, tačiau ir šio patogeno atžvilgiu tyrimų rezultatai prieštaringi [36-39]. Kombinuotos antibiotikų terapijos veiksmingumas įrodytas, jeigu infekciją sukèlè DAA pasižyminčios padermès [40, 41]. M. Tumbarello ir kt. (2012) atlikta retrospektyvi analizè su karbapenemazę produkuojančiomis K. pneumoniae bakteriemijomis ITS parode, kad tikslinè terapija didelèmis meropenemo dozėmis kartu su kolistinu ar tigeciklinu reikšmingai mažino mirštamumą [42].

Antibiotikų terapijos siaurinimas ir gydymo trukmė. Antibakterinio veikimo siaurinimas ir vartojimo trukmès mažinimas rekomenduojamas sepsio gydymo gairèse [43]. Nauda - mažeja atsparumas antibiotikams, retesni nepageidaujami reiškiniai, mažesnè gydymo kaina [44]. D. Mokart ir kt. (2014) pastebejjo, kad ITS sepsiu sergančių pacientų antibakterinis gydymas siaurinamas tik apie 50 proc. atvejų, nors sukèlejas yra nustatytas. Randomizuotų studijų, vertinančių antibakterinio gydymo siaurinimo efektyvumą, vis dar stokojama. Keleto perspektyviujjų studijų (2014) rezultatai parodé, kad antibiotikų terapijos siaurinimas nepadidino kritinių būklių pacientų mirštamumo [45-47]. Sukèlejjo jau- 
trumas antibiotikams in vitro gali ir nekoreliuoti su jautrumu in vivo dèl antibiotikų farmakokinetinių savybių, todèl kai kuriais individualizuoto gydymo atvejais, racionalu palikti tikslinę platesnio veikimo antibiotikų terapiją, negu nustatyta in vitro [48].

Randomizuotų tyrimų apie antibiotikų terapijos trukmę, gydant GNLB, nèra, todèl ji turètų būti nustatoma individualiai, atsižvelgiant i klinikini paciento atsaką, visuomet siekiant ją trumpinti. GNLB atveju dažniausia rekomenduojama trukmé - apie 7 dienas, atsižvelgiant ị židinio kontrolę.

Prokalcitonino testo verte parodo, kada galima nutraukti antibiotikų terapiją, todèl prokalcitonino žymuo gali būti naudojamas antibiotikų terapijos trukmei optimizuoti. A. Prkno ir kt. (2016) atliktos metaanalizès (1075 pacientai sergantys sepsiu) rezultatai parodè, kad remiantis prokalcitonino dinamika, galima statistiškai reikšmingai sutrumpinti antibiotiku terapijos trukmę, mirštamumui nekintant 28 dienas [49]. Prokalcitonino patikimos vertès, kuriai esant galima būtų nutraukti antibiotikų terapiją dèl invidualių paciento kriterijų, nenustatyta. Daugelio ekspertų nuomone, racionalus intervalas nurodomas $0,25 \mathrm{ng} / \mathrm{ml}-4 \mathrm{ng} / \mathrm{ml}$ [49].

Prognozè, mirštamumo rizikos veiksniai. Literatūros duomenimis, GNLB sukeltas mirštamumas varijuoja ir siekia $11,72-60$ proc. $[8,10,12,13,50]$. W. Sligl ir kt. (2015) atliko per 8 metus ITS ịgytos GNLB 429 atvejų analizę, nustate 49 proc. mirštamumą ir jo rizikos veiksnius: imunosupresinè būklè, nuolatinis gliukokortikoidų vartojimas, išeminè širdies liga, netinkama empiriné antibiotikų terapija [8]. Lietuvoje 2015 m. atlikta retrospektyvi 4 metų GNLB analizè parodè šiuos mirštamumo rizikos veiksnius: pirminè bakteriemija, sukèlèjo DAA, kraujotakos nepakankamumas, lètinè obstrukcinè plaučių liga, chemoterapija, dirbtinè plaučių ventiliacija [50].

\section{Išvados}

Hospitalinė gramneigiamų lazdelių bakteriemija vis dažnesnè ITS. Dažniausi jos sukèlejai - K. pneumoniae, $P$. aeruginosa, A. baumannii ir E. coli. Jų padermèms būdingas dauginis atsparumas antibiotikams. Dauginio atsparumo antibiotikams rizikos veiksniai - su sveikatos priežiūra sietina infekcija, senyvas amžius, buvęs plataus veikimo antibiotiku vartojimas, kritinè paciento būklè (poreikis gydymui ITS), agranulocitozè, medicininiai svetimkūniai, dirbtinè plaučiu ventiliacija. Greitas sunkios būklès atpažinimas, infekcijos židinio nustatymas, adekvačios antibiotikų terapijos skyrimas ir optimizuota jos trukmé gerina ligos baigti bei mažina atsparumo antibiotikams vystymąsi. Mirštamumo rizikos veiksniai - gramneigamų lazdelių bakteriemijos sukėlejo padermès dauginis atsparumas antibiotikams, imunosupresinè būklè, lètinès širdies, kraujagyslių bei plaučių ligos, dirbtinè plaučių ventiliacija bei neadekvati empirinè antibiotikų terapija.

\section{Literatūra}

1. Søgaard M. Diagnosis and prognosis of patients with community-acquired bacteremia. Aarhus University 2009. http://kea. au.dk/file/pdf/292.pdf.

2. Viscoli C. Bloodstream infections: the peak of the iceberg. Virulence 2016;7(3):248-51. https://doi.org/10.1080/21505594.2016.1152440

3. Bell T, O'Grady N. Prevention of central line-associated bloodstream infections Infectious Disease Clinics of North America 2017;31(3):551-559. https://doi.org/10.1016/j.idc.2017.05.007

4. Vallés J, Ferrer R. Bloodstream infection in the ICU. Infectious Disease Clinics North America 2009;23(3):557-69. https://doi.org/10.1016/j.idc.2009.04.005

5. Timsit J, Laupland K. Update on bloodstream infections in ICUs. Current Opinion Critical Care 2012;18(5):479-86. https://doi.org/10.1097/MCC.0b013e328356cefe

6. Hurley J, Guidet B, Offenstadt G, Maury E. Endotoxemia and mortality prediction in ICU and other settings: underlying risk and co-detection of gramnegative bacteremia are confounders. Critical Care 2012;16(4):R148. https://doi.org/10.1186/cc11462

7. Matteo B. Bloodstream infections in the intensive care unit. Virulence 2016;7(3):267-279. https://doi.org/10.1080/21505594.2015.1134072

8. Sligl W, Dragan T, Smith SW. Nosocomial gram-negative bacteremia in intensive care: epidemiology, antimicrobial susceptibilities, and outcomes. International Journal Infectious Diseases 2015;37:129-34. https://doi.org/10.1016/j.ijid.2015.06.024

9. Karchmer A. Bloodstream infections: the problem and the challenge. International Journal Antimicrobial Agents 2009;34S:S2-4. https://doi.org/10.1016/S0924-8579(09)70556-4

10. Sligl W, Taylor G, Brindley P. Five years of nosocomial gramnegative bacteremia in a general intensive care unit: epidemiology, antimicrobial susceptibility patterns, and outcomes. International Journal Infectious Diseases 2006;10(4):320-5. https://doi.org/10.1016/j.ijid.2005.07.003

11. Tabah A, Koulenti D, Laupland K. Characteristics and determinants of outcome of hospital-acquired bloodstream infections in intensive care units: the Eurobact international cohort study. Intensive Care Medicine 2012;38(12):1930-45. https://doi.org/10.1007/s00134-012-2695-9

12. Sante L, Aguirre-Jaime A, Miguel M, Ramos M, Pedroso Y, Lecuona M. Epidemiological study of secondary bloodstream infections: The forgotten issue. Journal Infection Public Health 2019;12(1):37-42. https://doi.org/10.1016/j.jiph.2018.08.011

13. Stryjewski M, Boucher W. Gram-negative bloodstream in- 
fections. International Journal Antimicrobial Agents 2009;S21S25.

https://doi.org/10.1016/S0924-8579(09)70561-8

14. Gustinetti G, Mikulska M. Bloodstream infections in neutropenic cancer patients: a practical update. Virulence 2016;7(3):280297.

https://doi.org/10.1080/21505594.2016.1156821

15. Alqarni A, Kantor E, Grall N, et al. Clinical characteristics and prognosis of bacteraemia during postoperative intra-abdominal infections. Critical Care 2018;22:175.

https://doi.org/10.1186/s13054-018-2099-5

16. Paczosaa M. Klebsiella pneumoniae: going on the offense with a strong defense. Microbiology Molecular Biology Reviews 2016; 80(3):629-661.

https://doi.org/10.1128/MMBR.00078-15

17. Girometti N, Lewis R. Klebsiella pneumoniae bloodstream infection: epidemiology and impact of inappropriate empirical therapy. Medicine (Baltimore) 2014;93:298-309.

https://doi.org/10.1097/MD.0000000000000111

18. Micek S, Lloyd A, Ritchie D, et al. Pseudomonas aeruginosa bloodstream infection: importance of appropriate initial antimicrobial treatment. Antimicrobial Agents and Chemotherapy 2005;49:1306-1311.

https://doi.org/10.1128/AAC.49.4.1306-1311.2005

19. Lambert P. Mechanisms of antibiotic resistance in pseudomonas aeruginosa. Journal Royal Society Medicine 2002;95:22.

20. Chopra T, Marchaim D. Epidemiology of bloodstream infections caused by acinetobacter baumannii and impact of drug resistance to both carbapenems and ampicillin-sulbactam on clinical outcomes. Antimicrobial Agents Chemotherapy 2013;57:6270-5.

https://doi.org/10.1128/AAC.01520-13

21. Falagas ME, Karageorgopoulos DP. Pandrug resistance (PDR), extensive drug resistance (XDR), and multidrug resistance (MDR) among gram-negative bacilli: need for international harmonization in terminology. Clinical Infectious Diseases 2008;46(7):1121-1122.

https://doi.org/10.1086/528867

22. Tumbarello M, Sanguinetti M. Predictors of mortality in patients with bloodstream infections caused by extended-spectrum- $\beta$ lactamase-producing enterobacteriaceae: importance of inadequate initial antimicrobial treatment. Antimicrobial Agents Chemotherapy 2007;51:1987-1994.

https://doi.org/10.1128/AAC.01509-06

23. Adrie C, Garrouste-Orgeas M, Ibn Essaied W, et al, OUTCOMEREA study group. Attributable mortality of ICU-acquired bloodstream infections: impact of the source, causative microorganism, resistance profile and antimicrobial therapy. J Infect 2017;74(2):131-141.

https://doi.org/10.1016/j.jinf.2016.11.001

24. Singhal N, Kumar M. MALDI-TOF mass spectrometry: an emerging technology for microbial identification and diagnosis. Frontiers Microbiology 2015;6:791. https://doi.org/10.3389/fmicb.2015.00791
25. Vlek AL, Bonten M. Direct matrix-assisted laser desorption ionization time-of-flight mass spectrometry improves appropriateness of antibiotic treatment of bacteremia. PLoS One 2012;7(3):e32589.

https://doi.org/10.1371/journal.pone.0032589

26. Guo SY, Zhou Y, Hu Q. Procalcitonin is a marker of gramnegative bacteremia in patients with sepsis. American Journal Medical Sciences 2015;349:499-504.

https://doi.org/10.1097/MAJ.0000000000000477

27. Retamar P, Portillo MM, López-Prieto M. Impact of inadequate empirical therapy on the mortality of patients with bloodstream infections: a propensity score-based analysis. Antimicrobial Agents Chemotherapy 2012;56:472.

https://doi.org/10.1128/AAC.00462-11

28. Zilberberg M, Shorr A, Micek S. Multi-drug resistance, inappropriate initial antibiotic therapy and mortality in gram-negative severe sepsis and septic shock: A retrospective cohort study. Critical Care 2014;18:596.

https://doi.org/10.1186/s13054-014-0596-8

29. Micek S, Welch E, Khan J. Resistance to empiric antimicrobial treatment predicts outcome in severe sepsis associated with gram-negative bacteremia. Journal Hospital Medicine 2011;6:405-10. https://doi.org/10.1002/jhm.899

30. Giannella M, Trecarichi E, De Rosa F, Del Bono V, Bassetti M, Lewis R. Risk factors for carbapenem-resistant Klebsiella pneumoniae bloodstream infection among rectal carriers: a prospective observational multicentre study. Clinical Microbiology Infection 2014;20:1357-62.

https://doi.org/10.1111/1469-0691.12747

31. Aloush V, Navon-Venezia S, Seigman-Igra Y, Cabili S, Carmeli Y. Multidrug-resistant pseudomonas aeruginosa: risk factors and clinical impact. Antimicrobial Agents Chemotherapy 2006; 50:43-48.

https://doi.org/10.1128/AAC.50.1.43-48.2006

32. Fournier P, Richet H. The epidemiology and control of acinetobacter baumannii in health care facilities. Clinical Infectious Diseases 2006;42:692-699.

https://doi.org/10.1086/500202

33. Playford E, Craig J, Iredell J. Carbapenem-resistant acinetobacter baumannii in intensive care unit patients: risk factors for acquisition, infection and their consequences. Journal Hospital Infection 2007;65:204-211.

https://doi.org/10.1016/j.jhin.2006.11.010

34. Hussein K, Sprecher H, Mashiach T, Oren I, Kassis I, Finkelstein R. Carbapenem resistance among klebsiella pneumoniae isolates: risk factors, molecular characteristics, and susceptibility patterns. Infection Control Hospital Epidemiology 2009;30:666-671.

https://doi.org/10.1086/598244

35. Tumbarello M, Trecarichi E, Tumietto F, Del Bono V, De Rosa F, Bassetti M. Predictive models for identification of hospitalized patients harboring KPC-producing klebsiella pneumoniae. Antimicrobial Agents Chemotherapy 2014;58:3514-20. 
https://doi.org/10.1128/AAC.02373-13

36. Kumar A, Zarychanski R, Light B, Parrillo J, Maki D, Simon D, Laporta D. Cooperative antimicrobial therapy of septic shock (CATSS) database research group. Early combination antibiotic therapy yields improved survival compared with monotherapy in septic shock: a propensity-matched analysis. Critical Care Medicine 2010;38:1773-85.

https://doi.org/10.1097/CCM.0b013e3181eb3ccd

37. Díaz-Martín A, Martínez-González ML, Ferrer R, Ortiz-Leyba $\mathrm{C}$, Piacentini E. Antibiotic prescription patterns in the empiric therapy of severe sepsis: combination of antimicrobials with different mechanisms of action reduces mortality. Critical Care 2012; 16:R223.

https://doi.org/10.1186/cc11869

38. Safdar N, Handelsman J, Maki D. Does combination antimicrobial therapy reduce mortality in gram-negative bacteraemia? A meta-analysis. Lancet Infectious Diseases 2004;4:519-27. https://doi.org/10.1016/S1473-3099(04)01108-9

39. Paul M, Lador A, Grozinsky-Glasberg S, Leibovici L. Beta lactam antibiotic monotherapy versus beta lactam-aminoglycoside antibiotic combination therapy for sepsis. Cochrane Database Systematic Review 2014. https://doi.org/10.1002/14651858.CD003344.pub3

40. Martínez JA, Cobos-Trigueros N, Soriano A, Almela M, Ortega M, Marco F. Influence of empiric therapy with a beta-lactam alone or combined with an aminoglycoside on prognosis of bacteremia due to gram-negative microorganisms. Antimicrobial Agents Chemotherapy 2010;54(9):3590.

https://doi.org/10.1128/AAC.00115-10

41. Qureshi Z, Paterson D, Potoski B, Kilayko M, Sandovsky G, Sordillo E. Treatment outcome of bacteremia due to KPCproducing klebsiella pneumoniae: superiority of combination antimicrobial regimens. Antimicrobial Agents and Chemotherapy $2012 ; 56(4): 2108-13$.

https://doi.org/10.1128/AAC.06268-11

42. Tumbarello M, Viale P, Viscoli C, Trecarichi EM, Tumietto F, Marchese A. Predictors of mortality in bloodstream infections caused by klebsiella pneumoniae carbapenemase-producing k. pneumoniae: importance of combination therapy. Clinical Infectious Diseases 2012; 55:943-50.

https://doi.org/10.1093/cid/cis588

43. Dellinger R, Levy M, Rhodes A, Annane D, Gerlach H, Opal S. Surviving sepsis campaign guidelines committee including the pediatric subgroup. Surviving Sepsis Campaign: international guidelines for management of severe sepsis and septic shock, 2012. Intensive Care Medicine 2013; 39:165-228. https://doi.org/10.1007/s00134-012-2769-8

44. Masterton RG. Antibiotic de-escalation. Critical Care Clinics 2011; 27:149-162.

https://doi.org/10.1016/j.ccc.2010.09.009

45. Mokart D, Slehofer G, Lambert J, Sannini A, Chow-Chine L, Brun J. De-escalation of antimicrobial treatment in neutropenic patients with severe sepsis: results from an observational study. Intensive Care Medicine 2014;40:41-9. https://doi.org/10.1007/s00134-013-3148-9

46. Garnacho-Montero J, Gutiérrez-Pizarraya A, Escoresca-Ortega A, Corcia-Palomo Y, Fernández-Delgado E, Herrera-Melero I. De-escalation of empirical therapy is associated with lower mortality in patients with severe sepsis and septic shock. Intensive Care Medicine 2014;40(1):32-40.

https://doi.org/10.1007/s00134-013-3077-7

47. Leone M, Bechis C, Baumstarck K, Lefrant JY, Albanèse J, Jaber S. AZUREA network investigators. De-escalation versus continuation of empirical antimicrobial treatment in severe sepsis: a multicenter non-blinded randomized noninferiority trial. Intensive Care Medicine 2014; 40(10):1399-408.

https://doi.org/10.1007/s00134-014-3411-8

48. Harris P, Ferguson J. Antibiotic therapy for inducible AmpC beta-lactamase-producing gram-negative bacilli: what are the alternatives to carbapenems, quinolones and aminoglycosides? International Journal Antimicrobial Agents 2012;40:297-305. https://doi.org/10.1016/j.ijantimicag.2012.06.004

49. Prkno A, Wacker C, Brunkhorst F, Schlattmann P. Procalcitonin-guided therapy in intensive care unit patients with severe sepsis and septic shock-a systematic review and meta-analysis. Critical Care 2013;17:R291.

https://doi.org/10.1186/cc13157

50. Adukauskiene D, Valanciene D. Analysis of gram-negative rod bacteremia in the surgical and medical ICU. Critical Care 2015;19(Suppl 1):P92.

https://doi.org/10.1186/cc14172

\section{NOSOCOMIAL GRAM-NEGATIVE BACILLARY BACTEREMIA IN INTENSIVE CARE UNIT: WHAT WE SHOULD KNOW? \\ D. Adukauskienė, M. Jurevičius, V. Micpovilytė, D. Valančienè, A. Dambrauskienė}

Keywords: bacteremia, gram-negative rods, intensive care unit. Summary

Nosocomial gram-negative rod bacteremia is usually diagnosed in intensive care unit and is associated with increasing morbidity and mortality reaching up to $60 \%$. The most common strains of these pathogens are characterized by multi-drug resistance, when initial prescription of antibiotic is often inappropriate, but only early administration of adequate antibiotic therapy improves patient outcomes. Therefore, it is very important to recognize this severe condition early, to predict possible pathogens, to evaluate risk factors to acquire the multi-drug resistant strains and to present background for adequate empirical antibiotic therapy as soon as possible. This article reviews the literature on nosocomial gramnegative rod bacteremia, displays it's classification, the epidemiological situation in intensive care units, principles of diagnosis and treatment, risk factors for nosocomial multi-drug resistant strain of infection and mortality.

Correspondence to: jurevicius.mantas@gmail.com

Gauta 2020-04-15 